\title{
Organizing Students' Independent Work: An Approach for Graduate and Undergraduate Students
}

\author{
Aleksandra Zakharova \\ State University of Management, Moscow, Russian Federation \\ Elena Soboleva \\ Far Eastern Federal University, Vladivostok, Russian Federation \\ Galia Biserova \\ Elabuga Institute (branch) of Kazan (Volga Region) Federal University \\ Elabuga, Russian Federation
}

\begin{abstract}
In the modern educational process, the proportion of independent work for students increases. The aim of this study is to develop an approach to organizing student work based on their level of education (bachelor's or master's). Creating a new approach based on the level of learning is important because it will improve the quality of independent work of students and increase their level of motivation for independent learning. A survey study was carried out among 210 bachelor's students (second year) and 60 master's students (first year) to determine their preferences towards the structure and types of independent work and its assessment. (The total number of respondents were 270.) Respondents were selected based on their level of education. A total of 76 lecturers were also selected to take part in the study. In this paper, we describe an approach to organizing student independent work based on the survey results. We found that the independent work of undergraduate students consisted of working with given materials $(80 \%)$ and literature searches $(20 \%)$. Most of the lecturer respondents considered work with ready-to-use educational materials to be the most favorable for bachelor's students $(70 \%)$, with much fewer considering independent or mixed work to be more effective $(8 \%$ and $22 \%$, respectively). The final module testing includes the questions addressed in the classroom and the topics students studied independently. The practical significance is that the developed approach to organizing student independent work can be used by any institution of higher education within the Bologna Process.
\end{abstract}

Keywords: higher education institution; independent work; methods of independent work 


\section{Introduction}

New trends, progress, and shifting principles affect educational systems all over the world. Today, the world's educational systems are aimed at continuous improvement and self-development. It is not enough to learn once; it is necessary to develop skills throughout life, as progress happens quickly. Around the world, education has adopted a focus on the self-development of the student, which is achieved by increasing the proportion of independent work in the learning process.

Education in Great Britain is based on the principle of lifelong learning, which is based on competence, personal development, and competitiveness. Each person should directly participate in the political, cultural, and social life of the country (Kogan, 2000).

Students studying at higher education institutions in Germany spend more time studying independently than under supervision $(\mathrm{Wu}, 2017)$. In general, they spend around 20 hours studying in the classroom per week. In-class lessons provide only the basics, while the depth of the issue is studied independently by the student. Similarly, countries such as the United States and Japan allocate about $50-60 \%$ of the work plan to the student's independent work.

The issue of organizing students' independent work has also been identified in Brazil since higher educational institutions are actively introducing distance education technologies (Da Silva et al., 2019). Studies conducted by Brazilian scientists have shown the interest of students in and the effectiveness of new distance technologies, which contribute to personal development and better learning.

Malaysian scholars have emphasized the importance of professional development and the reorganization of faculty work in improving the quality of independent activity. A motivated faculty member is more inclined to and interested in scholarly progress, which ultimately affects the quality of their work. A teacher who knows the latest advancements in their field or even contributes to the advancements is better at delivering information to students, both in and outside the classroom. As a result, students perform better and raise the rating of their educational institution. Therefore, the concept of high-quality higher education based on high-quality independent work begins with teacher motivation (Salim et al., 2010).

Whatever approaches are adopted by different countries to improve education, their main goal is to provide quality education to the student. The main component of such education is self-learning through independent work.

Today, the main task of the Russian higher education system is to train qualified specialists with professional competencies and the capacity for self-development. Students' knowledge is evaluated through the acquired competencies according to the specialty standard. However, it is impossible to design students' independent work without the participation of the students themselves and 
considering their level of education (bachelor's or master's). Therefore, it is relevant to study the organization of students' independent work taking into account their educational level.

Many researchers have paid attention to the problem of students' independent work organization, focusing on the importance of internet technologies in the educational process (Aminov \& Khodzhaieva, 2017; Fedorova, 2016; Garieev et al., 2018). However, independent work organization based on educational level has not been studied enough, which adds novelty to this study. The study is also novel in that there is a need to review traditional teaching methods at the university and offer new methodological approaches using modern technologies that optimize the educational process and increase students' motivation to work independently and search for teaching materials without lecturers. Modern scientific works have confirmed the novelty of the study regarding the peculiarities of students' independent work in various aspects (Leushin \& Leushina, 2017; Sviridova \& Timoshenko, 2018). The difference in views on the issue of student independent work is to turn to different methodological approaches (traditional and modern). In addition, the difference is explained by the level of readiness to increase the proportion of independent work of students and opportunities for its implementation. Our own approach takes the position of increasing the level of motivation of students to do independent work and opportunities for its implementation with the help of modern technologies. Thus, our specific research problem is based on the need to develop an approach to independent work of students in a modern educational process created on the basis of modern technologies.

\section{Literature Review}

In the modern educational process, there is a need to develop new methodological approaches to student independent work. These approaches can be used in any institution of higher education within the Bologna Process, which involves reforming higher education systems to create favorable conditions for the educational process using modern methods and approaches to education (Kaçaniku, 2020). Many international researchers have raised the issue of students' independent work organization. Previous research has indicated the role of independent work in developing communicative-interactive competence (Sali, 2017; Shevchuk et al., 2018), its importance in developing self-organization and self-management skills (Abilkhamitkyzy et al., 2014; Ualiyeva \& Murzalinova, 2016), and the need for a new model of independent work organization that considers numerous factors that can affect students' individual learning (Soliyeva, 2017). The potential gaps in the field relate to lack of a unified methodological approach to the implementation of independent work of students, and the use of modern technologies and innovations.

The field is based on the works of both foreign and national researchers who analyzed various aspects of students' independent work in the modern educational process and whose works are important for understanding the problematic issue of student independent work. Many international authors have highlighted the importance of internet resources in the organization of student 
independent work (Gray et al., 2019; Naik et al., 2020; Parikh \& Verma, 2002). They consider the importance of the ever-increasing volume of information, changes of the individual learning trajectory, and growing mobility, namely unlimited opportunities for independent study in terms of time and place.

An indispensable skill for a future specialist is the ability to work with information and to think critically, which can be developed through working with internet resources (Gray et al., 2019; Medeiros et al., 2019; Naik et al., 2020). Nowadays, science and new technologies have a significant impact on the socio-economic development of all countries, and the level of development of each country is determined by the availability of advanced information technologies (Klochkova et al., 2019). The importance of modern technology has been stressed in the works of both foreign and national researchers (Pushkina, 2011; Ualiyeva et al., 2016). Students entering and studying at institutions of higher education today belong to the so-called Generation Z. These students have an excellent command of modern technology and easily master information online. Thanks to special electronic training programs, students can watch video lectures, work with scientific literature, write essays, make presentations, take surveys and tests, master courses, and even do practical classes. Aminov and Khodzhaieva (2017) pointed out that with this technology, information can be stored indefinitely, edited at any time, and used for interactive learning.

One of the promising areas in improving the independent work of students is blogging using special software that can analyze and edit information (Garieev et al., 2018). The most critical problem is the control of the information that students master through independent study. The introduction of the modular rating system of learning encourages students to study because of its clear differentiation of grades and minimization of the subjective influence of the lecturer. This approach improves the quality of learning and engages students in independent work (Sviridova \& Timoshenko, 2018).

Leushin and Leushina (2017) recommended differentiating students' independent work based on their level of basic training. It is assumed that graduates of gymnasiums or lyceums who studied according to a certain program should have an equal share of classroom and independent hours. On the contrary, other students should have more in-class hours. This approach is explained by the fact that better prepared students can handle $50 \%$ of the activities undertaken as independent work, while students with no experience in specific subjects must first learn the basics in the classroom.

The issue of organizing independent work is a topic of discussion in many countries, including Russia. The application of modern technology to education and online learning is very relevant. Sviridova and Timoshenko (2018) discussed the evaluation of independent work with the help of the modular rating system. Other studies have explored the necessity of differentiating the amount of independent work based on students' level of training (Leushin \& Leushina, 2017) and the importance of an integrated system for managing the learning process (Ostapenko \& Plekhova, 2018). Thus, the most relevant and important aspects of 
the scientific literature are represented by the peculiarities of independent student work, the problem of using modern technologies in independent student work, and using new methodological approaches in independent student work.

\section{Problem Statement}

The development of a new approach to the organization of independent work by students emerged in connection with the need to reorient work plans to consider the students' level of training. Classroom hours should be reduced in favor of independent studies without losing the quality of education. Independent student work should be supported by all methodological developments. Through independent work, students are subject to learning to organize their own activities effectively and efficiently. This includes planning their work, understanding the system of tasks, distinguishing the main from the secondary, adjusting their independent work, analyzing the results, and identifying shortcomings and developing ways to address them. Thus, gaps in previous research are related to the lack of new methodological approaches to the implementation of independent student work and the need to revise curricula and develop new methods based on student practice and independent work (Leushin \& Leushina, 2017; Sviridova \& Timoshenko, 2018).

Hence, the aim of this study is to develop an approach for organizing student work considering their level of education (bachelor's or master's). The objectives of the study are to: conduct a survey among undergraduate and graduate students on their vision of independent work in terms of its structure, type, and form convenient for them; and conduct a survey among lecturers of undergraduate and graduate students on their vision of student independent work as to its structure, type, and form useful for them.

\section{Method}

The research was based on the methodological concepts introduced by these researchers: Gheorge (2016) and Sofronova and Nikulina (2019). The study presents descriptive statistics to establish certain evidence, namely the preferences of bachelor's and master's students regarding the preferred structure, type, and form of independent work. The practical purpose of the work is to establish the percentage of students who prefer various types of independent work, and does not involve any more complex forms of statistical research. The results of this study will themselves be the basis for further research in this area.

\subsection{Materials}

The study was conducted at two Moscow universities (State University of Management and Far Eastern Federal University) and at the Elabuga Institute (branch) of Kazan (Volga Region) Federal University. Since the aim of this research was to develop an approach to organizing students' independent work based on their level of education, the first step was to randomly survey students. The participating second-year bachelor's students were surveyed during the second semester of 2020, whereas the first-year master's students were surveyed during the first semester of the same year. The randomly selected undergraduate and graduate students were divided into two groups: group 1 included the 
bachelor's students and group 2 the master's students (see Table 1). The survey was conducted specifically among undergraduate and graduate students because these categories of students have a different vision of independent work due to their level of education. Second-year bachelor's students were selected because they will have already possessed knowledge of basic concepts about such types of work as independent work. First-year master's students will have already formed their opinion during the previous years of study.

Table 1. Criteria for sampling respondents

\begin{tabular}{|l|l|l|l|l|}
\hline Criterion & \multicolumn{2}{|c|}{ Group 1 (n) } & \multicolumn{2}{c|}{ Group 2 (n) } \\
\hline Level of study & Bachelor's & 210 & Master's & 60 \\
\hline \multirow{2}{*}{ Gender } & Male & 105 & Male & 30 \\
\cline { 2 - 5 } & Female & 105 & Female & 30 \\
\hline
\end{tabular}

At the same time, we conducted a similar study among lecturers to determine their opinion on the effectiveness of different forms of independent work based on their observations and practical experience. Lecturers from the same two universities in Moscow (State University of Management and Far Eastern Federal University) and the Elabuga Institute (branch) of Kazan (Volga Region) Federal University were invited to take part in the study, and included mostly those who taught classes to students who participated in the survey. A total of 76 lecturers were invited across the three institutions, and included 39 females and 37 males.

The survey was conducted through a written questionnaire, with students from different courses responding to the survey. The lecturer survey was conducted as an individualized questionnaire. The questionnaire was completed by the lecturers themselves at a time convenient to them.

The survey consisted of closed-ended questions aimed at understanding the students' and lecturers' attitude towards independent work (see Table 2).

Table 2. Survey questions

\begin{tabular}{|l|l|l|}
\hline Survey questions & Student respondents & Lecturer respondents \\
\hline & $\begin{array}{l}\text { What structure of } \\
\text { independent work do you } \\
\text { think is the most fitting? }\end{array}$ & $\begin{array}{l}\text { What structure of } \\
\text { independent work do you } \\
\text { think is the most } \\
\text { appropriate for the } \\
\text { students? }\end{array}$ \\
\cline { 2 - 3 } & $\begin{array}{l}\text { What form of independent } \\
\text { work would you like to use } \\
\text { in independent study? }\end{array}$ & $\begin{array}{l}\text { What types of independent } \\
\text { work would you like to } \\
\text { use? }\end{array}$ \\
\hline $\begin{array}{l}\text { What types of assessment } \\
\text { do you consider most } \\
\text { convenient for you? }\end{array}$ & $\begin{array}{l}\text { What types of assessment } \\
\text { for the student's individual } \\
\text { work do you consider most } \\
\text { convenient for you? }\end{array}$ \\
\hline
\end{tabular}

There were three answer options for the first and second questions and seven for the third. Respondents were to select only one option by putting an appropriate mark (+) in the answer field. 
After the survey, the responses of student and lecturer respondents were analyzed using the statistical method and the results were converted into percentages using Statistica software. Based on the analysis, the optimal structure of students' independent work according to respondents' educational level (bachelor's or master's) was determined.

\section{Results}

\subsection{Students' Questionnaire Results}

The aim of this study is to develop an approach for organizing students' independent work considering their level of education (bachelor's or master's). Therefore, the first question in the questionnaire asked student respondents to choose the structure of independent work that helps them to master subjects most comfortably (see Table 3). Analysis showed that the students were least inclined to search for learning materials independently according to the provided plan and with no other methodological help. This can be attributed to the low level of students' independent work, their unwillingness to search for materials on their own, lack of open access learning materials, low level of technical competence using modern technologies, or lack of motivation to study and search for learning materials.

Table 3: The structure of independent work

\begin{tabular}{lcc}
\hline \multicolumn{1}{c}{ Structure } & $\begin{array}{c}\text { Second-year } \\
\text { bachelor's students } \\
(\%)\end{array}$ & $\begin{array}{c}\text { First-year } \\
\text { master's } \\
\text { students (\%) }\end{array}$ \\
\hline $\begin{array}{l}\text { Working with materials provided by a } \\
\text { lecturer }\end{array}$ & 64 & 21 \\
$\begin{array}{l}\text { Literature searches according to the work } \\
\text { plan }\end{array}$ & 5 & 7 \\
$\begin{array}{l}\text { Working with materials provided by a } \\
\text { lecturer + literature searching according to } \\
\text { the work plan }\end{array}$ & 31 & 72 \\
\hline
\end{tabular}

Analysis showed that when studying independently, $64 \%$ of the undergraduate students preferred to work exclusively with the materials they receive from their lecturers. Such results indicate that undergraduate students are not yet ready for independent research as the majority of these respondents $(64 \%)$ chose the option of being provided the necessary materials by lecturers, which indicates a low level of independent work. Twenty-one percent of the first-year master's students as well as sixty-four percent of the undergraduate students preferred to work with ready-to-use learning materials or a mixed structure. Only $7 \%$ of the graduate students preferred to search for scientific literature independently according to the work plan, which indicates unpreparedness for independent work and independent research for educational materials. More than two-thirds of the graduate students $(72 \%)$ preferred working with both the provided materials and doing independent research. Twenty-one percent of the master's students preferred only working with ready-made materials.

The second question of the survey wanted to determine what types of independent work and forms of evaluation students preferred (Table 4). 
Table 4: Types of independent work and forms of supervision

\begin{tabular}{lll}
\hline $\begin{array}{l}\text { Types of independent work and } \\
\text { assessments }\end{array}$ & $\begin{array}{l}\text { Second-year } \\
\text { bachelor's } \\
\text { students (\%) }\end{array}$ & $\begin{array}{l}\text { First-year } \\
\text { master's students } \\
\text { (\%) }\end{array}$ \\
\hline Types of independent work & & \\
\hline $\begin{array}{l}\text { Working with manuals and other scientific } \\
\text { literature }\end{array}$ & 17 & 7 \\
$\begin{array}{l}\text { Working with electronic systems } \\
\text { Working with manuals and other scientific }\end{array}$ & 53 & 12 \\
literature + working with electronic systems & 30 & 81 \\
\hline Types of assessment & & \\
\hline Testing & 26 & 11 \\
Essay writing & 33 & 13 \\
Presentation & 22 & 42 \\
Answering test questions (written or oral) & 7 & 4 \\
Practical assignments & 8 & 17 \\
Mini research projects & 2 & 12 \\
Mixed assessment & 2 & 1 \\
\hline
\end{tabular}

Table 4 shows that of all types of independent work, both the bachelor's and master's students least of all preferred to work only with printed literature $(17 \%$ and $7 \%$, respectively). More than half of the undergraduate students (53\%) indicated their preference solely for electronic systems. Almost a third of the bachelor's students (30\%) chose a mixed type of independent work. Just over $80 \%$ of the master's students chose mixed forms of independent study. The percentage of graduate students willing to work with electronic systems alone is $41 \%$ less than that for undergraduate students. Moreover, $51 \%$ more of the graduate students chose a mixed approach compared to the undergraduate students.

After studying the materials, the student must pass a test, the result of which indicates their level of proficiency. Student respondents had to indicate which of seven types of assessment were most convenient to them (see Table 4). The second-year bachelor's students most preferred such assessment forms as testing (26\%), essay writing (33\%), and presentation (22\%). Only $19 \%$ of the students chose either answering test questions, practical tasks, mini research projects, or mixed forms of assessment. This shows that undergraduate students prefer assessments they are accustomed to from secondary school.

The results show that $42 \%$ of the first-year master's students preferred to create presentations and showcase them at seminars, which indicates motivation for independent work that involves creativity. In addition, 11\% chose the "testing" option. However, only $13 \%$ of these respondents preferred to write an essay. Only $12 \%$ of respondents chose the option of "mini research projects", which indicates a low level of readiness for independent work and independent research for the necessary training materials. The assessment indicators that received the lowest score were answering questions (4\%) and mixed assessment (1\%).

\subsection{Lecturers' Questionnaire Results}

The faculty survey showed slightly different results than that for the students. This survey relied on the subjective assessment of lecturers, who will have been 
more familiar with the real productivity and efficiency of students, rather than impartial assessment. The lecturer respondents had a more consolidated opinion on the structure of students' independent work than the student respondents (Table 5).

Table 5: The structure of independent study as viewed by lecturer respondents

\begin{tabular}{|c|c|c|}
\hline Structure & $\begin{array}{l}\text { Second-year } \\
\text { bachelor's } \\
\text { students (\%) }\end{array}$ & $\begin{array}{l}\text { First-year master's } \\
\text { students }(\%)\end{array}$ \\
\hline $\begin{array}{l}\text { Working with materials provided by a } \\
\text { lecturer }\end{array}$ & 70 & 10 \\
\hline $\begin{array}{l}\text { Literature searches according to the work } \\
\text { plan }\end{array}$ & 8 & 20 \\
\hline $\begin{array}{l}\text { Working with materials provided by a } \\
\text { lecturer + literature searches according to the } \\
\text { work plan }\end{array}$ & 22 & 70 \\
\hline
\end{tabular}

Most of the lecturer respondents $(70 \%)$ considered the work with ready-to-use educational materials to be the most favorable for bachelor's students, with much fewer respondents considering independent or mixed work to be more effective ( $8 \%$ and $22 \%$, respectively).

Regarding independent work for master's students, the situation was reversed: $70 \%$ of the lecturer respondents considered the mixed-type activity to be the most effective, while $20 \%$ were willing to allow master's students to work independently. Only $10 \%$ of these respondents favored the use of given materials. The lecturers' opinion in percentage ratio matches that of the first-year master's students (Table 3).

Table 6 presents the responses to the second and third questions of the lecturer survey. These responses differ from those given by student respondents, with the differences being more significant for the bachelor's students.

Table 6: Types of independent work and evaluation as viewed by lecturer respondents

\begin{tabular}{lll}
\hline \multicolumn{1}{c}{$\begin{array}{c}\text { Types of independent work and } \\
\text { assessments }\end{array}$} & $\begin{array}{c}\text { Second-year } \\
\text { bachelor's } \\
\text { students (\%) }\end{array}$ & $\begin{array}{c}\text { First-year } \\
\text { master's students } \\
\text { (\%) }\end{array}$ \\
\hline Types of independent work & & \\
\hline $\begin{array}{l}\text { Working with manuals and other scientific } \\
\text { literature }\end{array}$ & 14 & 9 \\
Working with electronic systems & 29 & 3 \\
Working with manuals and other scientific & 57 & 88 \\
literature + working with electronic systems & & \\
\hline Types of assessment & 31 & 10 \\
\hline Testing & 13 & 29 \\
Essay writing & 4 & 14 \\
Presentation & 6 & 9 \\
Answering test questions (written or oral) & 16 & 16 \\
Practical assignments & & \multicolumn{2}{l}{} \\
\hline
\end{tabular}




\begin{tabular}{lll}
\hline Mini research projects & 16 & 22 \\
Mixed assessment & 14 & 0 \\
\hline
\end{tabular}

The lecturers considered mixed activities with a greater share of independent searching to be more effective (57\% compared to 30\% among the bachelor's students [Table 4]). The use of electronic systems was preferred by $29 \%$ of the lecturers compared to $53 \%$ of the bachelor's students. The lecturers' opinion on which forms of independent work are more effective with master's students almost coincided with how the master's students saw their independent activity. Both categories of respondents ( $88 \%$ lecturers versus $81 \%$ master's students) were inclined to the mixed type of learning where the dominant form of work is literature searching.

The greatest differences were expectedly related to the forms of assessment and control. While the undergraduate students emphasized testing (26\%), writing an essay $(33 \%)$, and creating a presentation $(22 \%)$ (Table 4$)$, the lecturers preferred testing $(31 \%)$, practical assignments $(16 \%)$, mini research projects $(16 \%)$, mixed assessment $(14 \%)$, and essay writing $(13 \%)$ (Table 6$)$. The lecturers preferred more rigorous forms of control with a large share of practical and academic skills implementation, which are easier to evaluate. Creating a presentation was mentioned by a mere $4 \%$ and the use of test questions by only $6 \%$ of the lecturers.

While the graduate students favored assessment via presentation (42\%; Table 4), the lecturers preferred essay writing $(29 \%)$, mini research projects $(22 \%)$, and practical assignments (16\%) as types of assessment for graduate students. Only $14 \%$ of the lecturers chose presentations. As for other forms of assessment favored by the lecturers for graduate students, $10 \%$ favored tests, $9 \%$ chose answering test questions, and none were interested in mixed types of assessment. Thus, the lecturers preferred assessment tasks that demand students to be independent learners. Such types of evaluation are better suited to the learning objectives of master's students and enable lecturers to form a clearer picture of student progress.

The results therefore show that the independent work of the undergraduate students consisted of working with given materials (80\%) and literature searching (20\%). Most of the lecturers considered the work with ready-to-use educational materials to be the most favorable for bachelor's students (70\%), and much fewer considered independent or mixed work to be more effective ( $8 \%$ and $22 \%$, respectively).

\section{Discussion - Theoretical Contributions}

Independent work of students requires the development of new methodological approaches using modern technologies and pedagogical innovations. The results of the survey showed differences in the preferences of bachelor's and master's students and faculty regarding the structure and types of independent work and its evaluation. Based on the data presented in Tables 1-4, an approach to organizing students' independent work was developed. Regarding bachelor's students, $80 \%$ of independent learning materials should come from the lecturer. 
Examples include textbooks, instructions, practical guides, and other educational literature. Students should search for the remaining $20 \%$ of sources themselves.

The significance of the findings lies in the possibility of using the developed approach for independent work of students. In addition, the results obtained can be used to develop curricula and programs in order to create an equal balance between classroom and independent work of students. In the context of a more meaningful understanding of the research problem, our study offers an approach to the implementation of independent work. This approach can be used in the educational process to improve the quality of independent work of students in general.

Based on the study's findings, it can be determined that in order to improve the quality of students' independent work, it is necessary to solve problems related to the low level of motivation of students to independently search for materials. Therefore, the developed approach is aimed at students to search for educational materials on their own, and not to use ready-made materials. Moreover, the problems associated with independent work can be solved by expanding the types of independent work and forms of supervision.

Our research correlates with prior studies based on the fact that the approaches to organizing student work are based on student preferences for digital systems (Apuke \& Iyendo, 2018; Rusli et al., 2020). Another similarity is that students are more willing to work with electronic textbooks, online lectures, videos, and web searches than with printed materials (Betül Yilmaz \& Orhan, 2010; Byrne et al., 2002). Negative results are represented by the fact that students prefer to use educational materials prepared by lecturers, rather than looking for them on their own. In addition, students relying on the emergence of modern teaching methods does not completely exclude printed products because some students (especially undergraduates) prefer to get the basic materials from their lecturers in a printed form before doing a web search. Such results can be explained by the low level of independent work of students, non-use of modern teaching methods by lecturers, and unwillingness of students to fully transition to the emergence of digital technologies instead of printed versions of educational materials.

Independent learners can work with either digital or printed sources, but the load these sources impose on individual learners will vary depending on their learning experience. Undergraduate students should spend $70 \%$ of their time working with digital sources, such as electronic textbooks, videos, e-learning systems, and chat rooms. The remaining 30\% should be dedicated to printed literature, namely books, textbooks, tutorials, instructions, etc. As mentioned earlier, $80 \%$ of such materials, both digital and printed, should come from lecturers as a means of support. The majority of the undergraduate students in this study chose the following three forms of evaluation: testing, essay writing, and presentation (see Tables 2 and 4). The essay writing and presentation essentially imply that students focus on a single problem, while testing presents an opportunity to assess their knowledge of the entire topic. Most of the lecturers in this study expressed their preference for testing. 
In general, the results of our study are consistent with our initial assumptions. Unexpectedly, the results indicated that many students prefer to use ready-made teaching materials provided by lecturers, rather than independently searching for teaching materials. Based on this, it can be concluded that the developed approach to the organization of independent work of students will help increase the level of motivation of students to independently search for educational materials. The effectiveness of the developed method may be a subject of further research.

Compared to our developed approach to the organization of independent work of students, it has also been proposed that it be implemented through a creditmodule system (Nosirova et al., 2020). Similar studies have analyzed the effectiveness of a modular credit system, the advantages of which are its clear differentiation of grades and minimization of the subjective influence of the teacher (Sviridova \& Timoshenko, 2018). This study argues for the differentiation of students' independent work based on their level of education. Other authors also address differentiation by specialties, groups, and other indicators (Byrne et al., 2002; Leushin \& Leushina, 2017). In addition, what other research has in common with our research is that effective technologies are modern technologies that can be used by students both in preparation for classes and in classrooms (Pushkina, 2011; Ualiyeva et al., 2016).

The outcomes of our research are related to the educational process as a whole, as the developed approach allows for the organization of independent student work as one of the types of student work in any subject in order to maintain the quality of the educational process at a sufficient level.

\section{Conclusions}

The research proposes an approach to organizing students' independent work based on their educational level (bachelor's or master's). This approach focuses on the structure and types of independent activity and offers different forms of assessment.

The results of the survey showed that independent undergraduate students should receive $80 \%$ of materials from lecturers and find the remaining $20 \%$ of materials themselves to enhance their knowledge. Digital sources can account for $70 \%$ of their study materials, while the remaining $30 \%$ should be in printed form. According to the survey, graduate students prefer digital sources, so they should obtain $90 \%$ of materials via electronic learning systems and $10 \%$ from printed sources provided by lecturers.

Implementing the developed approach will help educators to adjust the structure of individual work according to students' capabilities and level of comprehension. The importance of tailoring students' independent work to their needs is reflected in the works of some international researchers. The suggested approach ensures that students better grasp the learning material and allows them to grow, make decisions, adapt to different situations, separate the main from the secondary, and learn how to apply knowledge in practice. 
Future research possibilities can be based on studying the effectiveness of the developed approach in the organization of independent work of students in the educational process. In addition, it is important to find new methodological approaches to the implementation of independent work of students, in particular with the help of modern technologies and pedagogical innovations.

\section{Acknowledgments}

Galia Biserova was supported by the Kazan Federal University Strategic Academic Leadership Program.

\section{Funding}

This research did not receive any specific grant from funding agencies in the public, commercial, or not-for-profit sectors.

\section{Conflict of Interest}

This research has no conflict of interest.

\section{Availability of Data and Material}

Data will be available on request.

\section{Ethical Approval}

The research was conducted ethically in accordance with the World Medical Association Declaration of Helsinki. The research was approved by the local ethics committees of Far Eastern Federal University. Informed consent was signed by respondents.

\section{References}

Abilkhamitkyzy, R., Aimukhambet, Z. A., \& Sarekenova, K. K. (2014). Organization of independent work of students on credit technology. Procedia - Social and Behavioral Sciences, 143, 274-278. https://doi.org/10.1016/j.sbspro.2014.07.403

Aminov, I. B., \& Khodzhaieva, D. F. (2017). Современные технологии для эффективной организации самостоятельной работы студентов [Modern technologies for effective organization of students' independent work]. Молодой Уиеный, 3(137), 523-524. https:// moluch.ru/archive/137/38507/

Apuke, O. D., \& Iyendo, T. O. (2018). University students' usage of the internet resources for research and learning: Forms of access and perceptions of utility. Heliyon, 4(12), e01052. https://doi.org/10.1016/j.heliyon.2018.e01052

Betül Yılmaz, M., \& Orhan, F. (2010). The use of internet by high school students for educational purposes in respect to their learning approaches. Procedia - Social and Behavioral Sciences, 2(2), 2143-2150. https://doi.org/10.1016/j.sbspro.2010.03.296

Byrne, M., Flood, B., \& Willis, P. (2002). The relationship between learning approaches and learning outcomes: A study of Irish accounting students. Accounting Education, 11(1), 27-42. https://doi.org/10.1080/09639280210153254

Da Silva, W. B., Amaro, R., \& Mattar, J. (2019). Distance education and the Open University of Brazil: History, structure, and challenges. International Review of Research in Open and Distributed Learning, 20(4), 99-115. http://www.irrodl.org/index.php/irrodl/article/view/4132

Fedorova, I. А. (2016). Использование интернет-ресурсов в самостоятельной работе студентов технических специальностей по иностранному языку [The use of 
internet resources in the independent work of students of technical specialties in a foreign language]. Мup Науки, 4(5), 1-7. https://cyberleninka.ru/article/n/ispolzovanie-internet-resursov-vsamostoyatelnoy-rabote-studentov-tehnicheskih-spetsialnostey-poinostrannomu-yazyku

Garieev, A. А., Shykhova, O. F., \& Shykhov, Yu. A. (2018). Организация самостоятельной работы студентов на основе учебных блогов [Organization of students' independent work on the basis of educational blogs]. Образование u Наука, 20(3), 117-139. https:// doi.org/10.17853/1994-5639-2018-3-117-139

Gheorge, I. B. (2016). Forming professional competences of students in higher educational organizations based on the organization of independent work: Monograph. TIU.

Gray, A. C., Diezel, H., \& Steel, A. (2019). The use of learning technologies in complementary medicine education: Results of a student technology survey. Advances in Integrative Medicine, 6(4), 164-180. https://doi.org/10.1016/j.aimed.2019.04.001

Kaçaniku, F. (2020). Towards quality assurance and enhancement: The influence of the Bologna Process in Kosovo's higher education. Quality in Higher Education, 26(1), 32-47. https:// doi.org/10.1080/13538322.2020.1737400

Klochkova, E., Tyurina, Y., Chernov, S., Glembotskaya, G. (2019). Methods for evaluating economy information potential. Revista Espacios, 40(38), 29. chromeextension:/ / efaidnbmnnnibpcajpcglclefindmkaj/viewer.html?pdfurl=https\%3A \%2F\%2Fwww.revistaespacios.com\%2Fa19v40n38\%2Fa19v40n38p29.pdf\&clen=1 93352\&chunk=true

Kogan, M. (2000). Lifelong learning in the UK. European Journal of Education, 35(3), 243. https://doi.org/10.1111/1467-3435.00031

Leushin, I. O., \& Leushina, I. V. (2017). Некоторые проблемы организации самостоятельной работы студентов в техническом вузе [Some problems of organizing students' independent work in a technical university]. Педагогика Высшей Школы, 6(213), 51-56. https://cyberleninka.ru/article/n/nekotoryeproblemy-organizatsii-samostoyatelnoy-raboty-studentov-v-tehnicheskom-vuze

Medeiros, E., Cruz, K., Lucena, J. P. O., \& Da Silva, L. A. (2019). Student satisfaction and causes of abandonment in distance education in undergraduate courses in a public institution of higher education in Northeastern Brazil. International Journal of Business Management and Economic Research (IJBMER), 10(4), 1619-1626. chromeextension:/ / efaidnbmnnnibpcajpcglclefindmkaj/viewer.html?pdfurl=https\%3A \%2F\%2Fwww.ijbmer.com\%2Fdocs\%2Fvolumes\%2Fvol10issue4\%2Fijbmer20191 00401.pdf\&clen $=1002069$ \&chunk $=$ true

Naik, G., Chitre, C., Bhalla, M., \& Rajan, J. (2020). Impact of use of technology on student learning outcomes: Evidence from a large-scale experiment in India. World Development, 127, 104736. https:// doi.org/10.1016/j.worlddev.2019.104736

Nosirova, D. T. Q., Pardaeva, Z. U., \& Khummamatova, K. K. (2020). The main forms of organization of independent work of students un the credit-module system. International Journal of Progressive Sciences and Technologies, 23(2). https://ijpsat.ijsht-journals.org/index.php/ijpsat/article/view/2438/1413

Ostapenko, A. V., \& Plekhova, Y. О. (2018). Совершенствование организации самостоятельной работы студентов как путь повышения качества юридического образования [Improvement of the organization of students' independent work as a way to improve the quality of legal education]. Педагогика. Bопросы Теоии и Практики, 4(12), 12-15. https://doi.org/10.30853/pedagogy.2018.4.2 
Parikh, M., \& Verma, S. (2002). Utilizing internet technologies to support learning: An empirical analysis. International Journal of Information Management, 22(1), 27-46. https://doi.org/10.1016/S0268-4012(01)00038-X

Pushkina, G. G. (2011). Самостоятельная работа студентов вуза: компетентностный подход и внедрение интернет-технологий [Independent work of university students: Competence approach and implementation of internet-technologies]. Гуманитарные Науки, 3, 94-100.

https://cyberleninka.ru/article/n/samostoyatelnaya-rabota-studentov-vuzakompetentnostnyy-podhod-i-vnedrenie-internet-tehnologiy

Rusli, R., Rahman, A., \& Abdullah, H. (2020). Student perception data on online learning using heutagogy approach in the Faculty of Mathematics and Natural Sciences of Universitas Negeri Makassar, Indonesia. Data in Brief, 29, 105152. https://doi.org/10.1016/j.dib.2020.105152

Sali, O. B. (2017). Самостійна робота судентів як засіб формування комунікативноінтерактивної компетентності [Students' self-directed work as a formation of communicative-interactive competence]. Засоби Навчальної та Науково-Дослідної Роботи, 49, 142-153.

https:/ / www.google.com/url?sa=t\&rct=j\&q=\&esrc=s\&source=web\&cd=\&ved= 2ahUKEwixgNqP5rj1AhVEzqQKHdBoCgIQFnoECAMQAQ\&url=http\%3A\%2F \%2Fjournals.hnpu.edu.ua\%2Findex.php\%2Fsciencemeans\%2Farticle\%2Fdownlo ad\%2F711\%2F836\&usg=AOvVaw1ATdy5pDiaOW9hYHH1LN4j

Salim, M., Mara, K. P., Melaka, B., Kamarudin, H., Begam, M., \& Kadir, A. (2010). Factors affecting organizational commitment among lecturers in higher educational institution in Malaysia. Kolej Profesional MARA Bandar Melaka, 12(2), 100-116. https:// www.semanticscholar.org/paper/FACTORS-AFFECTINGORGANIZATIONAL-COMMITMENT-AMONG-SalimMara/f39808c866b74ea5ba224cdfe9e99439e9832d41

Shevchuk, M. O., Kyrychok, I. I., \& Novgorodska, Y. G. (2018). Проблеми управління самостійною роботою студентів вищих навчальних закладів [Problems of management of independent work of students of higher educational institutions]. Молодий вчений, 1(53), 407-412. http://nbuv.gov.ua/UJRN/molv_2018_1(1)_97

Sofronova, V. V., \& Nikulina, L. P. (2019). Организация самостоятельной работы студентов в языковом вузе [Organization of students' independent work in a language university]. Мир Науки, Культуры, Образования, 5, 102-104. https://doi.org/10.24411/1991-5497-2019-00039

Soliyeva, M. А. (2017). Main components of organizing independent work of students. Достижения Науки и Образования, 4(14), 93-97. https:// scientifictext.ru/images/PDF/2017/DNO-4-17/DNO-4-17.pdf

Sviridova, G. F., \& Timoshenko, A. Y. (2018). Проблемы организации самостоятельной работы студентов вуза и пути их решения [Problems of the organization of independent work of students of pedagogical higher education institution and ways of their solution]. Вестник Алтайского Государственного Педагогического Университета, 2(39), 21-25.

ttps://journals-altspu.ru/vestnik/article/view/1235/1166

Ualiyeva, N. T., \& Murzalinova, A. Z. (2016). Organization of individual work of students under competence-oriented approach to education in higher school. International Journal of Environmental \& Science Education, 11(14), 6540-6556. https://www.researchgate.net/publication/308400230_Organization_of_indivi dual_work_of_students_under_competenceoriented_approach_to_education_in_higher_school

Ualiyeva, N. T., Murzalinova, A. Z., \& Kucher, T. P. (2016). Competence-oriented independent work of students in higher education institutions: Characteristics, 
content and organization. International Review of Management and Marketing, 6(S3) 146-155. http://hdl.handle.net/20.500.12424/2484287

Wu, R. (2017). Academic socialization of Chinese doctoral students in Germany: Identification, interaction and motivation. European Journal of Higher Education, 7(3), 276-290. https:// doi.org/10.1080/21568235.2017.1290880 